4

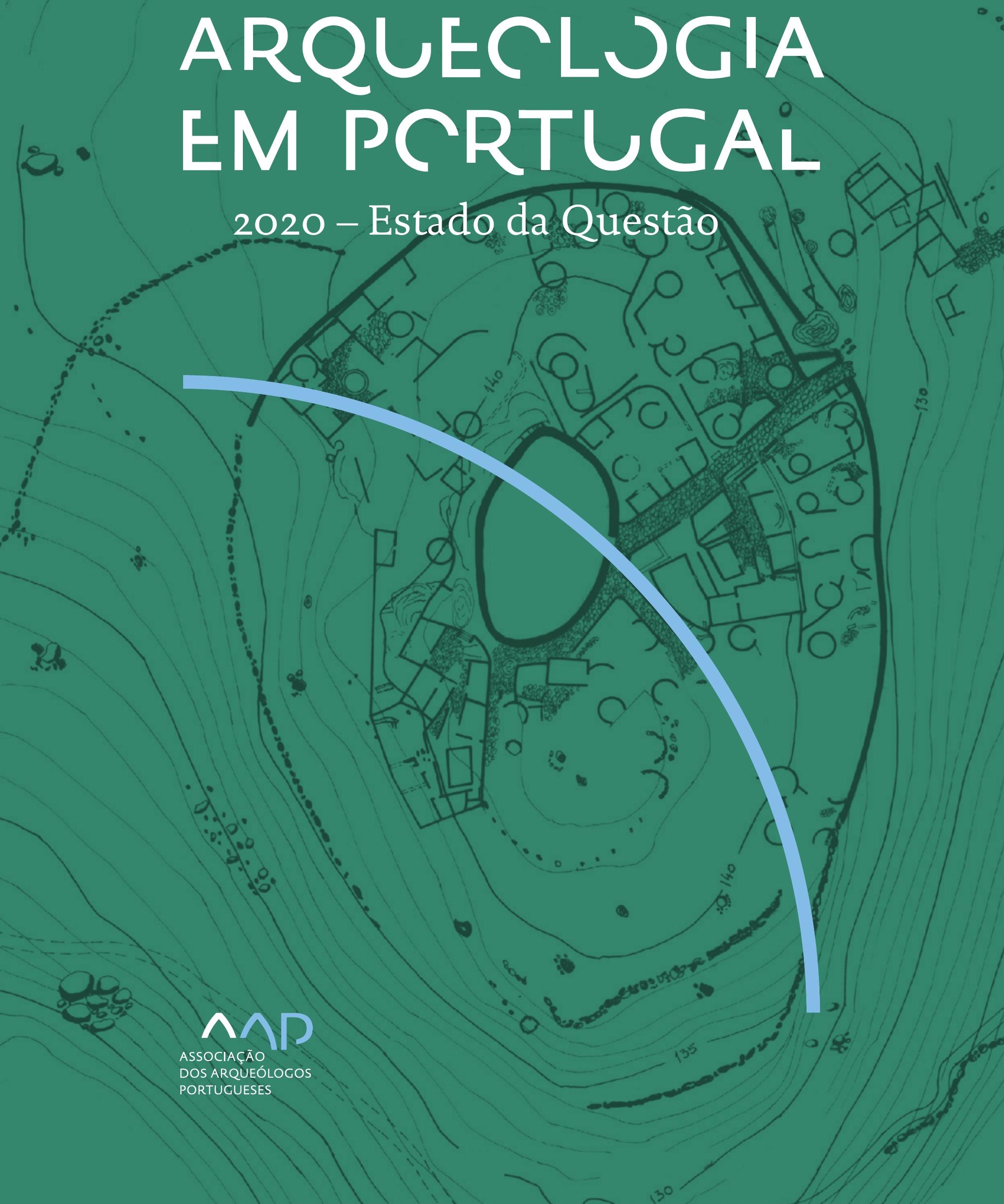


Coordenação editorial: José Morais Arnaud, César Neves e Andrea Martins Design gráfico: Flatland Design

AAP - ISBN: 978-972-9451-89-8

CITCEM - ISBN: 978-989-8970-25-1

Associação dos Arqueólogos Portugueses e CITCEM

Lisboa, 2020

O conteúdo dos artigos é da inteira responsabilidade dos autores. Sendo assim a Associação dos Arqueólogos Portugueses declina qualquer responsabilidade por eventuais equívocos ou questões de ordem ética e legal.

Desenho de capa:

Planta do castro de Monte Mozinho (Museu Municipal de Penafiel).

\section{$\hat{\wedge} \mathrm{P}$}

DOS ARQUEÓLOGOS PORTUGUESES

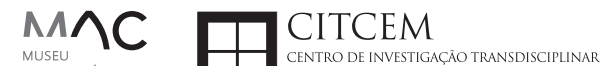
MUSEU
ARQUELLÓGICO
DO CARMO
U.PORTO

FLUP FACULDADE DE LETRAS
UNIVERSIDADE DO PORTO

Apoio

EC para a Ciência 


\section{Índice}

15 Prefácio

José Morais Arnaud

\section{Historiografia e Teoria}

17 Território, comunidade, memória e emoção: a contribuição da história da arqueologia (algumas primeiras e breves reflexões)

Ana Cristina Martins

25 Como descolonizar a arqueologia portuguesa?

Rui Gomes Coelho

41 Arqueologia e Modernidade: uma revisitação pessoal e breve de alguns aspetos da obra homónima de Julian Thomas de 2004

Vítor Oliveira Jorge

57 Dados para a História das Mulheres na Arqueologia portuguesa, dos finais do século XIX aos inícios do século XX: números, nomes e tabelas

Filipa Dimas / Mariana Diniz

73 Retractos da arqueologia portuguesa na imprensa: (in)visibilidades no feminino

Catarina Costeira / Elsa Luís

85 Arqueologia e Arqueólogos no Norte de Portugal Jacinta Bugalhão

101 Vieira Guimarães (1864-1939) e a arqueologia em Tomar: uma abordagem sobre o território e as gentes

João Amendoeira Peixoto / Ana Cristina Martins

115 Os memoráveis? A arqueologia algarvia na imprensa nacional e regional na presente centúria (2001-2019): características, visões do(s) passado(s) e a arqueologia

enquanto marca

Frederico Agosto / João Silva

129 A Evolução da Arqueologia Urbana e a Valorização Patrimonial no Barlavento Algarvio: Os casos de Portimão e Silves

Artur Mateus / Diogo Varandas / Rafael Boavida

\section{Gestão, Valorização e Salvaguarda do Património}

145 O Caderno Reivindicativo e as condições de trabalho em Arqueologia Miguel Rocha / Liliana Matias Carvalho / Regis Barbosa / Mauro Correia / Sara Simões / Jacinta Bugalhão / Sara Brito / Liliana Veríssimo Carvalho / Richard Peace / Pedro Peça / Cézer Santos

155 Os Estudos de Impacte Patrimonial como elemento para uma estratégia sustentável de minimização de impactes no âmbito de reconversões agrícolas Tiago do Pereiro

165 Salvaguarda de Património arqueológico em operações florestais: gestão e sensibilização Filipa Bragança / Gertrudes Zambujo / Sandra Lourenço / Belém Paiva / Carlos Banha / Frederico Tatá Regala / Helena Moura / Jacinta Bugalhão / João Marques / José Correia / Pedro Faria / Samuel Melro

179 Os valores do Património: uma investigação sobre os Sítios Pré-históricos de Arte Rupestre do Vale do Rio Côa e de Siega Verde José Paulo Francisco 
189 Conjugando recursos arqueológicos e naturais para potenciar as visitas ao Geoparque Litoral de Viana do Castelo (Noroeste de Portugal)

Hugo A. Sampaio / Ana M.S. Bettencourt / Susana Marinho / Ricardo Carvalhido

203 Áreas de Potencial Arqueológico na Região do Médio Tejo: Modelo Espacial Preditivo Rita Ferreira Anastácio / Ana Filipa Martins / Luiz Oosterbeek

223 Património Arqueológico e Gestão Territorial: O contributo da Arqueologia para a revisão do PDM de Avis

Ana Cristina Ribeiro

237 A coleção arqueológica do extinto Museu Municipal do Porto - Origens, Percursos e Estudos

Sónia Couto

251 Valpaços - uma nova carta arqueológica

Pedro Pereira / Maria de Fátima Casares Machado

263 Arqueologia na Cidade de Peniche

Adriano Constantino / Luís Rendeiro

273 Arqueologia Urbana: a cidade de Lagos como caso de Estudo Cátia Neto

285 Estratégias de promoção do património cultural subaquático nos Açores. O caso da ilha do Faial

José Luís Neto / José Bettencourt / Luís Borges / Pedro Parreira

297 Carta Arqueológica da Cidade Velha: Uma primeira abordagem

Jaylson Monteiro / Nireide Tavares / Sara da Veiga / Claudino Ramos / Edson Brito /

Carlos Carvalho / Francisco Moreira / Adalberto Tavares

311 Antropologia Virtual: novas metodologias para a análise morfológica e funcional Ricardo Miguel Godinho / Célia Gonçalves

\section{Didáctica da Arqueologia}

327 Como os projetos de Arqueologia podem contribuir para uma comunidade culturalmente mais consciente Alexandra Figueiredo / Claúdio Monteiro / Adolfo Silveira / Ricardo Lopes

337 Educação Patrimonial - Um cidadão esclarecido é um cidadão ativo! Ana Paula Almeida

351 A aproximação da Arqueologia à sala de aula: um caso de estudo no $3^{\circ}$ ciclo do Ensino Básico Luís Serrão Gil

363 Arqueologia 3.o - Pensar e comunicar a Arqueologia para um futuro sustentável Mónica Rolo

377 “Conversa de Arqueólogos" - Divulgar a Arqueologia em tempos de Pandemia Diogo Teixeira Dias

389 Escola Profissional de Arqueologia: desafios e oportunidades Susana Nunes / Dulcineia Pinto / Júlia Silva / Ana Mascarenhas

399 Os Museus de Arqueologia e os Jovens: a oferta educativa para o público adolescente Beatriz Correia Barata / Leonor Medeiros

411 O museu universitário como mediador entre a ciência e a sociedade: o exemplo da secção de arqueologia no Museu de História Natural e da Ciência da Universidade do Porto (MHNC-UP)

Rita Gaspar 
421 Museu de Lanifícios: Real Fábrica de Panos. Atividades no âmbito da Arqueologia Beatriz Correia Barata / Rita Salvado

427 Arqueologia Pública e o caso da localidade da Mata (Torres Novas) Cláudia Manso / Ana Rita Ferreira / Cristiana Ferreira / Vanessa Cardoso Antunes

431 Do sítio arqueológico ao museu: um percurso (também) didático Lídia Fernandes

447 Estão todos convidados para a Festa! E para dançar também... O projecto do Serviço Educativo do Museu Arqueológico do Carmo na $5^{\underline{a}}$ Edição da Festa da Arqueologia Rita Pires dos Santos

459 O “Clã de Carenque”, um projeto didático de arqueologia Eduardo Gonzalez Rocha

469 Mediação cultural: peixe que puxa carroça nas Ruínas Romanas de Troia Inês Vaz Pinto / Ana Patrícia Magalhães / Patrícia Brum / Filipa Santos

481 Didática Arqueológica, experiências do Projeto Mértola Vila Museu Maria de Fátima Palma / Clara Rodrigues / Susana Gómez / Lígia Rafael

\section{Arte Rupestre}

497 Os inventários de arte rupestre em Portugal Mila Simões de Abreu

513 O projeto FIRST-ART - conservação, documentação e gestão das primeiras manifestações de arte rupestre no Sudoeste da Península Ibérica: as grutas do Escoural e Maltravieso Sara Garcês / Hipólito Collado / José Julio García Arranz / Luiz Oosterbeek / António Carlos Silva / Pierluigi Rosina / Hugo Gomes / Anabela Borralheiro Pereira / George Nash / Esmeralda Gomes / Nelson Almeida / Carlos Carpetudo

523 Trabalhos de documentação de arte paleolítica realizados no âmbito do projeto PalæoCôa André Tomás Santos / António Fernando Barbosa / Luís Luís / Marcelo Silvestre / Thierry Aubry

537 Imagens fantasmagóricas, silhuetas elusivas: as figuras humanas na arte do Paleolítico Superior da região do Côa Mário Reis

$55^{1}$ Os motivos zoomórficos representados nas placas de tear de Vila Nova de São Pedro (Azambuja, Portugal) Andrea Martins / César Neves / José M. Arnaud / Mariana Diniz

571 Arte Rupestre do Monte de Góios (Lanhelas, Caminha). Síntese dos resultados dos trabalhos efectuados em 2007-2009 Mário Varela Gomes

599 Gravuras rupestres de barquiformes no Monte de S. Romão, Guimarães, Noroeste de Portugal Daniela Cardoso

613 Círculos segmentados gravados na Bacia do Rio Lima (Noroeste de Portugal): contributos para o seu estudo Diogo Marinho / Ana M.S. Bettencourt / Hugo Aluai Sampaio

631 Equídeos gravados no curso inferior do Rio Mouro, Monção (NW Portugal). Análise preliminar Coutinho, L.M. / Bettencourt, A.M.S / Sampaio, Hugo A.S

645 Paletas na Arte Rupestre do Noroeste de Portugal. Inventário preliminar Bruna Sousa Afonso / Ana M. S. Bettencourt / Hugo A. Sampaio 


\section{Pré-História}

661 O projeto Miño/Minho: balanço de quatro anos de trabalhos arqueológicos Sérgio Monteiro-Rodrigues / João Pedro Cunha-Ribeiro / Eduardo Méndez-Quintas / Carlos Ferreira / Pedro Xavier / José Meireles / Alberto Gomes / Manuel Santonja / Alfredo Pérez-González

677 A ocupação paleolítica da margem esquerda do Baixo Minho: a indústria lítica do sítio de Pedreiras 2 (Monção, Portugal) e a sua integração no contexto regional Carlos Ferreira / João Pedro Cunha-Ribeiro / Sérgio Monteiro-Rodrigues / Eduardo Méndez-Quintas / Pedro Xavier / José Meireles / Alberto Gomes / Manuel Santonja / Alfredo Pérez-González

693 O sítio acheulense do Plistocénico médio da Gruta da Aroeira Joan Daura / Montserrat Sanz / Filipa Rodrigues / Pedro Souto / João Zilhão

703 As sociedades neandertais no Barlavento algarvio: modelos preditivos com recurso aos SIG

Daniela Maio

715 A utilização de quartzo durante o Paleolítico Superior no território dos vales dos rios Vouga e Côa

Cristina Gameiro / Thierry Aubry / Bárbara Costa / Sérgio Gomes / Luís Luís / Carmen Manzano / André Tomás Santos

733 Uma perspetiva diacrónica da ocupação do concheiro do Cabeço da Amoreira (Muge, Portugal) a partir da tecnologia lítica Joana Belmiro / João Cascalheira / Célia Gonçalves

745 Novos dados sobre a Pré-história Antiga no concelho de Palmela. A intervenção arqueológica no sítio do Poceirão I

Michelle Teixeira Santos

757 Problemas em torno de Datas Absolutas Pré-Históricas no Norte do Alentejo Jorge de Oliveira

771 Povoamento pré-histórico nas áreas montanhosas do NO de Portugal: o Abrigo 1 de Vale de Cerdeira Pedro Xavier / José Meireles / Carlos Alves

783 Apreciação do povoamento do Neolítico Inicial na Baixa Bacia do Douro. A Lavra I (Serra da Aboboreira) como caso de estudo Maria de Jesus Sanches

797 O Processo de Neolitização na Plataforma do Mondego: os dados do Sector C do Outeiro dos Castelos de Beijós (Carregal do Sal)

João Carlos de Senna-Martinez / José Manuel Quintã Ventura / Andreia Carvalho / Cíntia Maurício

823 Novos trabalhos na Lapa da Bugalheira (Almonda, Torres Novas) Filipa Rodrigues / Pedro Souto / Artur Ferreira / Alexandre Varanda / Luís Gomes / Helena Gomes / João Zilhão

837 A pedra polida e afeiçoada do sítio do Neolítico médio da Moita do Ourives (Benavente, Portugal)

César Neves

857 Casal do Outeiro (Encarnação, Mafra): novos contributos para o conhecimento do povoamento do Neolítico final na Península de Lisboa.

Cátia Delicado / Carlos Maneira e Costa / Marta Miranda / Ana Catarina Sousa

873 Stresse infantil, morbilidade e mortalidade no sítio arqueológico do Neolítico Final/ Calcolítico ( $4^{\circ}$ e $3^{\circ}$ milénio a.C.) do Monte do Carrascal 2 (Ferreira do Alentejo, Beja) Liliana Matias de Carvalho / Sofia N. Wasterlain 
885 Come together: O Conjunto Megalítico das Motas (Monção, Viana do Castelo) e as expressões Campaniformes do Alto Minho Ana Catarina Basílio / Rui Ramos

899 Trabalhos arqueológicos no sítio Calcolítico da Pedreira do Poio Carla Magalhães / João Muralha / Mário Reis / António Batarda Fernandes

913 O sítio arqueológico de Castanheiro do Vento. Da arquitectura do sítio à arquitectura de um território João Muralha Cardoso

925 Estudo zooarqueológico das faunas do Calcolítico final de Vila Nova de São Pedro (Azambuja, Portugal): Campanhas de 2017 e 2018 Cleia Detry / Ana Catarina Francisco / Mariana Diniz / Andrea Martins / César Neves / José Morais Arnaud

943 As faunas depositadas no Museu Arqueológico do Carmo provenientes de Vila Nova de São Pedro (Azambuja): as campanhas de 1937 a 1967 Ana Catarina Francisco / Cleia Detry / César Neves / Andrea Martins / Mariana Diniz / José Morais Arnaud

959 Análise funcional de material lítico em sílex do castro de Vila Nova de S. Pedro (Azambuja, Portugal): uma primeira abordagem Rafael Lima

971 O recinto da Folha do Ouro 1 (Serpa) no contexto dos recintos de fossos calcolíticos alentejanos

António Carlos Valera / Tiago do Pereiro / Pedro Valério / António M. Monge Soares

\section{Proto-História}

987 Produção de sal marinho na Idade do Bronze do noroeste Português. Alguns dados para uma reflexão

Ana M. S. Bettencourt / Sara Luz / Nuno Oliveira / Pedro P. Simões / Maria Isabel C. Alves / Emílio Abad-Vidal

1001 A estátua-menir do Pedrão ou de São Bartolomeu do Mar (Esposende, noroeste de Portugal) no contexto arqueológico da fachada costeira de entre os rios Neiva e Cávado Ana M. S. Bettencourt / Manuel Santos-Estévez / Pedro Pimenta Simões / Luís Gonçalves

1015 O Castro do Muro (Vandoma/Baltar, Paredes) - notas para uma biografia de ocupação da Idade do Bronze à Idade Média

Maria Antónia D. Silva / Ana M. S. Bettencourt / António Manuel S. P. Silva / Natália Félix

1031 Do Bronze Final à Idade Média - continuidades e hiatos na ocupação de Povoados em Oliveira de Azeméis João Tiago Tavares / Adriaan de Man

1041 As faunas do final da Idade do Bronze no Sul de Portugal: leituras desde o Outeiro do Circo (Beja)

Nelson J. Almeida / Íris Dias / Cleia Detry / Eduardo Porfírio / Miguel Serra

1055 A Espada do Monte das Oliveiras (Serpa) - uma arma do Bronze Pleno do Sudoeste Rui M. G. Monge Soares / Pedro Valério / Mariana Nabais / António M. Monge Soares

1065 São Julião da Branca (Albergaria-a-Velha) - Investigação e valorização de um povoado do Bronze Final

António Manuel S. P. Silva / Paulo A. P. Lemos / Sara Almeida e Silva / Edite Martins de Sá

1083 Do castro de S. João ao Mosteiro de Santa Clara: notícia de uma intervenção arqueológica, em Vila do Conde Rui Pinheiro 
1095 O castro de Ovil (Espinho), um quarto de século de investigação - resultados e questões em aberto

Jorge Fernando Salvador / António Manuel S. P. Silva

1111 O Castro de Salreu (Estarreja), um povoado proto-histórico no litoral do Entre Douro e Vouga

Sara Almeida e Silva / António Manuel S. P. Silva / Paulo A. P. Lemos / Edite Martins de Sá

1127 Castro de Nossa Senhora das Necessidades (Sernancelhe): uma primeira análise artefactual Telma Susana O. Ribeiro

${ }_{1141}$ A cividade de Bagunte. O estado atual da investigação Pedro Brochado de Almeida

1153 Zoomorfos na cerâmica da Idade do Ferro no NW Peninsular: inventário, cronologias e significado Nuno Oliveira / Cristina Seoane

1163 Vasos gregos em Portugal: diferentes maneiras de contar a história do intercâmbio cultural na Idade do Ferro

Daniela Ferreira

1175 Os exotica da necrópole da Idade do Ferro do Olival do Senhor dos Mártires (Alcácer do Sal) no seu contexto regional

Francisco B. Gomes

\section{Antiguidade Clássica e Tardia}

1191 O uso de madeira como combustível no sítio da Quinta de Crestelos (Baixo Sabor): da Idade do Ferro à Romanização Filipe Vaz / João Tereso / Sérgio Simões Pereira / José Sastre / Javier Larrazabal Galarza / Susana Cosme / José António Pereira / Israel Espi

1207 Cultivos de Época Romana no Baixo Sabor: continuidade em tempos de mudança? João Pedro Tereso / Sérgio Simões Pereira / Filipe Santos / Luís Seabra / Filipe Vaz

1221 A casa romana na Hispânia: aplicação dos modelos itálicos nas províncias ibéricas Fernanda Magalhães / Diego Machado / Manuela Martins

1235 As pinturas murais romanas da Rua General Sousa Machado, n. ${ }^{5}$ 1, Chaves José Carvalho

1243 Trás do Castelo (Vale de Mir, Pegarinhos, Alijó) - Uma exploração agrícola romana do Douro

Tony Silvino / Pedro Pereira

1255 A sequência de ocupação no quadrante sudeste de Bracara Augusta: as transformações de uma unidade doméstica Lara Fernandes / Manuela Martins

1263 Os Mosaicos com decoração geométrica e geométrico-vegetalista dos sítios arqueológicos da área do Conuentus Bracaraugustanus. Novas abordagens quanto à conservação, restauro, decoração e datação Maria de Fátima Abraços / Licínia Wrench

1277 “Casa Romana” do Castro de São Domingos (Cristelos, Lousada): Escavação, Estudo e Musealização Paulo André de P. Lemos

1291 A arqueobotânica no Castro de Guifões (Matosinhos, Noroeste de Portugal): O primeiro estudo carpológico

Luís Seabra / Andreia Arezes / Catarina Magalhães / José Varela / João Pedro Tereso 
1305 Um Horreum Augustano na Foz do Douro (Monte do Castelo de Gaia, Vila Nova de Gaia) Rui Ramos

1311 Ponderais romanos na Lusitânia: padrões, formas, materiais e contextos de utilização Diego Barrios Rodríguez

1323 Um almofariz centro-itálico na foz do Mondego

Marco Penajoia

1335 Estruturas romanas de Carnide - Lisboa Luísa Batalha / Mário Monteiro / Guilherme Cardoso

1347 O contexto funerário do sector da "necrópole NO" da Rua das Portas de S. Antão (Lisboa): o espaço, os artefactos, os indivíduos e a sua interconectividade na interpretação do passado Sílvia Loja, José Carlos Quaresma, Nelson Cabaço, Marina Lourenço, Sílvia Casimiro, Rodrigo Banha da Silva, Francisca Alves-Cardoso

${ }_{1361}$ Povoamento em época Romana na Amadora - resultados de um projeto pluridisciplinar Gisela Encarnação / Vanessa Dias

1371 A Arquitectura Residencial em Mirobriga (Santiago do Cacém): contributo a partir de um estudo de caso Filipe Sousa / Catarina Felício

${ }_{1385}$ O fim do ciclo. Saneamento e gestão de resíduos nos edifícios termais de Mirobriga (Santiago do Cacém)

Catarina Felício / Filipe Sousa

1399 Balsa, Topografia e Urbanismo de uma Cidade Portuária Vítor Silva Dias / João Pedro Bernardes / Celso Candeias / Cristina Tété Garcia

1413 No Largo das Mouras Velhas em Faro (2017): novas evidências da necrópole norte de Ossonoba e da sua ocupação medieval Ricardo Costeira da Silva / Paulo Botelho / Fernando Santos / Liliana Nunes

1429 Instrumentos de pesca recuperados numa fábrica de salga em Ossonoba (Faro) Inês Rasteiro / Ricardo Costeira da Silva / Paulo Botelho

1439 A Necrópole Romana do Eirô, Duas Igrejas (Penafiel): intervenção arqueológica de 2016 Laura Sousa / Teresa Soeiro

1457 Ritual, descarte ou afetividade? A presença de Canis lupus familiaris na Necrópole Noroeste de Olisipo (Lisboa)

Beatriz Calapez Santos / Sofia Simões Pereira / Rodrigo Banha da Silva / Sílvia Casimiro / Cleia Detry / Francisca Alves Cardoso

1467 Dinâmicas económicas em Bracara na Antiguidade Tardia Diego Machado / Manuela Martins / Fernanda Magalhães / Natália Botica

1479 Cerâmicas e Vidros da Antiguidade Tardia do Edifício sob a Igreja do Bom Jesus (Vila Nova de Gaia) Joaquim Filipe Ramos

1493 Novos contributos para a topografia histórica de Mértola no período romano e na Antiguidade Tardia Virgílio Lopes

\section{8. Época Medieval}

1511 Cerâmicas islâmicas no Garb setentrional "português": algumas evidências e incógnitas Constança dos Santos / Helena Catarino / Susana Gómez / Maria José Gonçalves / Isabel Inácio / Gonçalo Lopes / Jacinta Bugalhão / Sandra Cavaco / Jaquelina Covaneiro / Isabel Cristina Fernandes / Ana Sofia Gomes 
1525 Contributo para o conhecimento da cosmética islâmica, em Silves, durante a Idade Média Rosa Varela Gomes

1537 Yábura e o seu território - uma análise histórico-arqueológica de Évora entre os séculos VIII-XII José Rui Santos

1547 A encosta sul do Castelo de Palmela - resultados preliminares da escavação arqueológica Luís Filipe Pereira / Michelle Teixeira Santos

1559 A igreja de São Lourenço (Mouraria, Lisboa): um conjunto de silos e de cerâmica medieval islâmica

Andreia Filipa Moreira Rodrigues

1571 O registo material de movimentações populacionais no Médio Tejo, durante os séculos XII-XIII. Dois casos de "sunken featured buildings", nos concelhos de Cartaxo e Torres Novas Marco Liberato / Helena Santos / Nuno Santos

1585 O nordeste transmontano nos alvores da Idade média. Notas para reflexão Ana Maria da Costa Oliveira

1601 Sepulturas escavadas na rocha do Norte de Portugal e do Vale do Douro: primeiros resultados do Projecto SER-NPVD

Mário Jorge Barroca / César Guedes / Andreia Arezes / Ana Maria Oliveira

1619 "Portucalem Castrum Novum" entre o Mediterrâneo e o Atlântico: o estudo dos materiais cerâmicos alto-medievais do arqueossítio da rua de D. Hugo, nํ. 5 (Porto) João Luís Veloso

1627 A Alta Idade Média na fronteira de Lafões: notas preliminares sobre a Arqueologia no Concelho de Vouzela

Manuel Luís Real / Catarina Tente

1641 Um conjunto cerâmico medieval fora de portas: um breve testemunho aveirense Susana Temudo

${ }_{1651}$ Os Lóios do Porto: uma perspetiva integrada no panorama funerário da Baixa Idade Média à Época Moderna em meios urbanos em Portugal

Ana Lema Seabra

1659 O Caminho Português Interior de Santiago como eixo viário na Idade Média Pedro Azevedo

1665 Morfologia Urbana: Um exercício em torno do Castelo de Ourém André Donas-Botto / Jaqueline Pereira

1677 Intervenção arqueológica na Rua Marquês de Pombal/Largo do Espírito Santo (Bucelas, Loures)

Florbela Estêvão / Nathalie Antunes-Ferreira / Dário Ramos Neves / Inês Lisboa

1691 O Cemitério Medieval do Poço do Borratém e a espacialidade funerária na cidade de Lisboa Inês Belém / Vanessa Filipe / Vasco Noronha Vieira / Sónia Ferro / Rodrigo Banha da Silva

1705 Um Espaço Funerário Conventual do séc. XV em Lisboa: o caso do Convento de São Domingos da Cidade Sérgio Pedroso / Sílvia Casimiro / Rodrigo Banha da Silva / Francisca Alves Cardoso

\section{9. Época Moderna e Contemporânea}

1721 Arqueologia Moderna em Portugal: algumas reflexões críticas em torno da quantificação de conjuntos cerâmicos e suas inferências históricas e antropológicas Rodrigo Banha da Silva / André Bargão / Sara da Cruz Ferreira

1733 Faianças de dois contextos entre os finais do século XVI e XVIII do Palácio dos Condes de Penafiel, Lisboa

Martim Lopes / Tomás Mesquita 
1747 Um perfil de consumo do século XVIII na foz do Tejo: O caso do Mercado da Ribeira, Lisboa Sara da Cruz Ferreira / Rodrigo Banha da Silva / André Bargão

1761 Os Cachimbos dos Séculos XVII e XVIII do Palácio Mesquitela e Convento dos Inglesinhos (Lisboa)

Inês Simão / Marina Pinto / João Pimenta / Sara da Cruz Ferreira / André Bargão / Rodrigo Banha da Silva

1775 "Tomar os fumos da erua que chamão em Portugal erua sancta». Estudo de Cachimbos provenientes da Rua do Terreiro do Trigo, Lisboa

Miguel Martins de Sousa / José Pedro Henriques / Vanessa Galiza Filipe

1787 Cachimbos de Barro Caulínitico da Sé da Cidade Velha (República de Cabo Verde)

Rodrigo Banha da Silva / João Pimenta / Clementino Amaro

1801 Algumas considerações sobre espólio não cerâmico recuperado no Largo de Jesus (Lisboa) Carlos Boavida

1815 Adereços de vidro, dos séculos XVI-XVIII, procedentes do antigo Convento de Santana de Lisboa (anéis, braceletes e contas)

Joana Gonçalves / Rosa Varela Gomes / Mário Varela Gomes

1837 Da ostentação, luxo e poder à simplicidade do uso quotidiano: arqueologia e simbologia de joias e adornos da Idade Moderna Portuguesa Jéssica Iglésias

1849 Os amuletos em Portugal - dos objetos às superstições: o coral vermelho Alexandra Vieira

1865 Cerâmicas de Vila Franca de Xira nos séculos XV e XVI Eva Pires

1879 «Não passa por teu o que me pertence». Marcas de individualização associadas a faianças do Convento de Nossa Senhora de Aracoeli, Alcácer do Sal Catarina Parreira / Íris Fragoso / Miguel Martins de Sousa

1891 Cerâmica de Leiria: alguns focos de produção

Jaqueline Pereira / André Donas-Botto

1901 Os Fornos na Rua da Biquinha, em Óbidos Hugo Silva / Filipe Oliveira

1909 A casa de Pêro Fernandes, contador dos contos de D. Manuel I: o sítio arqueológico da Silha do Alferes, Seixal (século XVI) Mariana Nunes Ferreira

1921 O Alto da Vigia (Sintra) e a vigilância e defesa da costa Alexandre Gonçalves / Sandra Santos

1937 O contexto da torre sineira da Igreja de Santa Maria de Loures Paulo Calaveira / Martim Lopes

1949 A Necrópole do Hospital Militar do Castelo de São Jorge e as práticas funerárias na Lisboa de Época Moderna Susana Henriques / Liliana Matias de Carvalho / Ana Amarante / Sofia N. Wasterlain

1963 SAND - Sarilhos Grandes Entre dois Mundos: o adro da Igreja e a Paleobiologia dos ossos humanos recuperados

Paula Alves Pereira / Roger Lee Jesus / Bruno M. Magalhães

1975 Expansão urbana da vila de Cascais no século XVII e XVIII: a intervenção arqueológica na Rua da Vitória no 15 a 17

Tiago Pereira / Vanessa Filipe

1987 Novos dados para o conhecimento do Urbanismo de Faro em época Moderna Ana Rosa 
1995 Um exemplo de Arqueologia Urbana em Alcoutim: o Antigo Edifício dos CTT Marco Fernandes / Marta Dias / Alexandra Gradim / Virgílio Lopes / Susana Gómez Martínez

2007 Palácio dos Ferrazes (Rua das Flores/Rua da Vitória, Porto): a cocheira de Domingos Oliveira Maia

Francisco Raimundo

2021 As muitas vidas de um edifício urbano: História, Arqueologia e Antropologia no antigo Recreatório Paroquial de Penafiel Helena Bernardo / Jorge Sampaio / Marta Borges

2035 O convento de Nossa Senhora da Esperança de Ponta Delgada: o contributo da arqueologia para o conhecimento de um monumento identitário João Gonçalves Araújo / N’Zinga Oliveira

2047 Arqueologia na ilha do Corvo... em busca da capela de Nossa Senhora do Rosário Tânia Manuel Casimiro / José Luís Neto / Luís Borges / Pedro Parreira

2059 Perdidos à vista da Costa. Trabalhos arqueológicos subaquáticos na Barra do Tejo Jorge Freire / José Bettencourt / Augusto Salgado

2071 Arqueologia marítima em Cabo Verde: enquadramento e primeiros resultados do projecto CONCHA

José Bettencourt / Adilson Dias / Carlos Lima / Christelle Chouzenoux / Cristóvão Fonseca / Dúnia Pereira / Gonçalo Lopes / Inês Coelho / Jaylson Monteiro / José Lima / Maria Eugénia Alves / Patrícia Carvalho / Tiago Silva

2085 Trabalhos arqueológicos na Cidade Velha (Ribeira Grande de Santiago, Cabo Verde): reflexões sobre um projecto de investigação e divulgação patrimonial André Teixeira / Jaylson Monteiro / Mariana Mateus / Nireide Tavares / Cristovão Fonseca / Gonçalo C. Lopes / Joana Bento Torres / Dúnia Pereira / André Bargão / Aurélie Mayer / Bruno Zélie / Carlos Lima / Christelle Chouzenoux / Inês Henriques / Inês Pinto Coelho / José Lima / Patrícia Carvalho / Tiago Silva

2103 A antiga fortificação de Quelba / Khor Kalba (E.A.U.). Resultados de quatro campanhas de escavações, problemáticas e perspectivas futuras Rui Carita / Rosa Varela Gomes / Mário Varela Gomes / Kamyar Kamyad

2123 Colónias para homens novos: arqueologia da colonização agrária fascista no noroeste ibérico Xurxo Ayán Vila / José Mạ . Señorán Martín 


\title{
A ENCOSTA SUL DO CASTELO DE PALMELA - RESULTADOS PRELIMINARES DA ESCAVAÇÃO ARQUEOLÓGICA
}

Luís Filipe Pereira ${ }^{1}$, Michelle Teixeira Santos ${ }^{2}$

\author{
RESUMO \\ Apresentação dos resultados preliminares da escavação arqueológica realizada na Encosta Sul do Castelo \\ de Palmela. \\ Palavras-chave: Castelo de Palmela, Islâmico, Silos, Encosta sul.
}

\begin{abstract}
Presentation of the preliminary results of the archaeological excavation in the South hillside of the Castle of Palmela.
\end{abstract}

Keywords: Castle of Palmela, Islamic, Silo, South hillside.

\section{INTRODUÇÃO}

O presente trabalho apresenta os resultados preliminares dos trabalhos arqueológicos realizados no âmbito do projecto de obra «Intervenção de Natureza Estrutural para Evitar Derrocadas na Encosta Sul do Castelo de Palmela» que decorreram entre novembro de 2018 e junho de 2019.

A intervenção arqueológica teve como director científico o arqueólogo Luís Filipe Pereira (Arqueohoje, Lda.), signatário do presente artigo, contando com a colaboração das arqueólogas Marina Évora (Arqueohoje, Lda.) e Michelle Teixeira Santos (Museu Municipal de Palmela), também signatária deste artigo, e a antropóloga Fátima Almeida. O tratamento das peças cerâmicas foi realizado com o apoio de Cláudia Sofia Oliveira (Museu Municipal de Palmela). As cerâmicas foram desenhadas por Maria Santos Constança, Marina Évora e Miguel Correia (Museu Municipal de Palmela). Os trabalhos de escavação contaram ainda com o auxílio de uma equipa de trabalhadores indiferenciados.

Este artigo, complementar ao poster científico, demonstra uma primeira abordagem sobre a leitura e interpretação dos resultados obtidos nos trabalhos de campo, a análise preliminar de uma selecção do espólio recolhido no interior de um silo de grandes dimensões, o silo 6 (U.E. [217/218]), cuja cronologia de utilização e encerramento remete para a última ocupação islâmica e a primeira ocupação cristã do castelo, com datação enquadrada entre os finais do século XII e o início do XIII.

\section{LOCALIZAÇÃO}

O Castelo de Palmela localiza-se no concelho de Palmela, pertencente ao distrito de Setúbal, e ocupa o topo de um cerro, com cerca de $252 \mathrm{~m}$ de altitude, e com as seguintes coordenadas geográficas (Sistema WGS84): Latitude $=38^{\circ} 33^{\prime} 56,73$ e Longitude $=$ $8^{\circ} 53^{\prime} 59,54$ (Figura 1).

A sua implantação beneficia estrategicamente de um amplo domínio visual sobre a paisagem circundante, podendo avistar a sul a cidade de Setúbal, o estuário do rio Sado e a costa atlântica até Sines, a poente os vales e o conjunto montanhoso da serra da Arrábida, a nascente a ampla planície do Ribatejo, e a norte o estuário do Rio Tejo.

\footnotetext{
1. Arqueohoje Lda. - Conservação e Restauro do Património Monumental, Lda; lpereira@arqueohoje.com

2. Museu Municipal de Palmela; mtsantos@cm-palmela.pt
} 


\section{CONTEXTOS E OBJECTIVOS}

O projecto de "Intervenção de natureza estrutural para evitar derrocadas nas encostas do Castelo de Palmela" contemplou a realização de trabalhos de natureza diversa, compreendendo trabalhos de engenharia estrutural que visava a estabilização da encosta sul, nascente e sudoeste do castelo.

Os trabalhos arqueológicos foram efectuados no âmbito das medidas preventivas para a minimização de impactos no solo e no subsolo para a execução do projecto, tendo em conta a sensibilidade e o potencial arqueológico do castelo, e com o objectivo de diagnosticar, caracterizar e registar a existência de vestígios arqueológicos preservados nesta área, e avaliar eventuais impactos negativos decorrentes da construção da antiga piscina da Pousada, nos finais dos anos 70 do século XX.

A investigação arqueológica do Castelo de Palmela inicia-se nos anos 9o do século passado sob a direcção da arqueóloga Isabel Cristina F. Fernandes. Os trabalhos realizados incidiram sobretudo na praça de armas, muralha norte e nascente, e permitiram identificar um conjunto habitacional da fase Omíada (século VIII), bem como uma sucessiva e continuada ocupação entre os séculos IX-X até à conquista definitiva do castelo pelos exércitos cristãos, no século XII (Fernandes, 2004). É nesta fase que a ordem de Santiago se instala e cria sede no castelo, onde mantém um comendador-cavaleiro e uma pequena guarnição de freires-cavaleiros.

\section{A INTERVENÇÃO ARQUEOLÓGICA}

\subsection{Metodologia}

A realização da avaliação patrimonial do subsolo afecto à área de implantação do projecto de execução, nomeadamente através da determinação da dimensão da área arqueológica e da sua caracterização científica/patrimonial; do registo das sequências estratigráficas contribuíram para a salvaguarda das estruturas arqueológicas in loco e para o consolidar do conhecimento sobre a ocupação da fortificação.

A escavação das sondagens prévias fez-se pela decapagem sucessiva dos diferentes sedimentos identificados até ao substrato geológico, estéril em vestígios arqueológicos, ultrapassando a cota de afectação da obra prevista para interior do recinto do baluarte Sul. As diferentes fases dos trabalhos foram devidamente registadas através do preenchimento indi- vidualizado de uma ficha de unidade estratigráfica, para cada estrato/depósito/estrutura; de fotografia digital, em suporte gráfico (à escala 1:20) e topográfico, abrangendo todos os planos (inicial, intermédios e final), dos perfis dos cortes e as estruturas arqueológicas postas a descoberto. Para cada uma das quatro sondagens foram atribuídas unidades estratigráficas distintas a partir do [0o], [100], [200] e [300], respectivamente.

\subsection{A Escavação}

A escavação arqueológica focou-se na encosta sul do castelo, onde foram implantadas quatro sondagens no interior do recinto abaluartado e junto da muralha medieval (alçado sul) como o objectivo de intervencionar uma área total de $80 \mathrm{~m}^{2}$. As sondagens, com diferentes dimensões, foram distribuídas desde a parte central do Baluarte Sul até à área mais a poente deste recinto, privilegiando uma área que à partida não teve impacto negativo com a construção da piscina da Pousada do Castelo situada na parte mais a nascente do baluarte.

Implantou-se a sondagem 1 junto à base da Torre do Telegrafista tendo sido intervencionado um total de $26,7 \mathrm{~m}^{2}$. O afloramento rochoso surge a cerca de o,40 $\mathrm{m}$ de profundidade, e encontra-se também por baixo da base da torre do Telegrafista servindo de base de assentamento das primeiras fiadas de pedra do aparelho da torre, solução construtiva observada noutras partes do pano de muralha medieval (Islâmico e Cristão) do castelo. Nesta sondagem identificaram-se vestígios de cronologia medieval islâmica, caracterizado por dois silos, restos osteológicos humanos e a fundação de um muro em alvenaria, e vestígios de cronologia moderna e contemporânea, na qual se destaca um piso de argamassa.

A sondagem 2 foi implantada na zona mais a poente da plataforma do Baluarte Sul, junto da Torre 8 (do Miradouro), tendo sido intervencionado 7,5 $\mathrm{m}^{2}$ de área. A estratigrafia identificada era constituída por várias camadas de aterro, que regularizavam a plataforma do recinto do baluarte. O substrato geológico (arenito compacto), com declive acentuado para Sul, surge a cerca de 2,5 $\mathrm{m}$ de profundidade. Identificou-se um piso de argamassa, que apresentava características idênticas ao piso registado na sondagem 1, de cronologia moderna, e um silo de cronologia medieval cristão.

A sondagem 3 estava localizada entre as sondagens 1 e 2, e corresponde à maior área de escavação, com 
um total de $35,3 \mathrm{~m}^{2}$ intervencionados. Procurou-se aproximar esta sondagem do pano de muralha medieval, alçado sul, compreendido entre as torres do Telegrafista e a Torre 8. Só foi possível encostar a sondagem à muralha na área central da intervenção, em cerca de $3 \mathrm{~m}$ de comprimento, salvaguardando assim o coberto arbustivo e arbóreo existente. O substrato geológico surge a cerca de 1,10 $\mathrm{m}$ de profundidade, e o terreno apresenta-se aplanado/ regularizado. Foi neste estrato que foram escavados durante a ocupação islâmica do castelo, os nove silos de diferentes tamanhos, a vala de fundação de um muro (de construção e alinhamento semelhante ao registado na sondagem 1 ), bem como outras estruturas negativas associadas, eventualmente, a sistemas de drenagem de águas pluviais (U.E.'s [222] e [223]). A sondagem 4 foi implantada na parte mais central do baluarte e mais próxima à antiga piscina da Pousada do Castelo, tendo sido intervencionada uma área com 10,5 $\mathrm{m}^{2}$ e até à cota de afectação da obra, aos $4 \mathrm{~m}$ de profundidade. A estratigrafia revelou tratar-se de unidades de aterro utilizadas para regularizar o solo, e que contém inúmeros artefactos de ampla cronologia, sensivelmente desde o século $\mathrm{XIV} / \mathrm{XV}$ até ao século XX. A rocha base calcoarenítica apresenta-se em plataformas que intercalam com níveis mais arenoso muito compacto, e com declive abrupto para Sul. Desta sondagem apenas se destacam um resto de um muro (U.E. [309]), de função indeterminada, e o piso de argamassa (U.E. [305]) registado nas restantes sondagens. Também se identificaram alguns contextos resultantes das obras de restauro realizadas nas décadas de 30/40 do século passado pela DGEMN (Direcção Geral de Edifícios e Monumentos Nacionais), das adaptações resultantes da ocupação/utilização do castelo pelo Exército Português Transmissões Militares) e das obras de relacionadas com a construção da antiga piscina da Pousada do Castelo. A leitura da estratigrafia permitiu clarificar o comportamento do terreno natural e a influência da topografia na construção do baluarte sul. $\mathrm{O}$ afloramento rochoso surge aos $0,40 \mathrm{~m}$ de profundidade, observável no perfil norte, e surge em escamas até aos cerca dos $4 \mathrm{~m}$ de profundidade, sempre com acentuado declive para sul. Os sedimentos que compõem o enchimento do interior do baluarte correspondem a sucessivas camadas de aterro depositadas desde a rocha base, onde a muralha adossa e se sobrepõe, até ao nível mais regularizado existente no topo do baluarte.
De um modo geral, a estratigrafia do terreno é bastante homogénea, estendendo-se na horizontal em quase toda a área intervencionada, com excepção na sondagem 4 que se apresenta mais revolvida e alterada devido à proximidade com a antiga piscina, e associada à presença militar em especial na Torre dos Telegrafistas. As camadas que caracterizam os diferentes estratos são sedimentos de natureza arenosa, medianamente compactos, por vezes revolvidos, e apresentam uma coloração em tons castanhos, cinzentos e amarelos. A cultura material recolhida parece indicar que toda esta área foi sujeita a melhoramentos sobretudo no que respeita a nivelamento do solo, para a construção do baluarte sul no século XVII e centúrias seguintes.

\subsection{Resultados}

No total foram identificadas 38 estruturas, de funções por vezes distintas, que se inserem cronologicamente, desde o período medieval islâmico (silos, muro e valas) ao período contemporâneo (valas de infra-estruturas de saneamento e electricidade).

As estruturas arqueológicas melhor preservadas são de cronologia medieval e encontravam-se ao nível do subsolo, sensivelmente à cota do substrato geológico (Figura 2). Destes vestígios evidenciam-se os doze silos de cronologia medieval (11 islâmicos e 1 cristão), escavados integralmente, com excepção dos silos 1 e 7 que ficaram salvaguardados no perfil sul, além do silo io junto ao perfil oeste. Estas estruturas destinadas ao armazenamento de bens alimentares terão sido eventualmente, construídas entre os séculos IX-X e utilizadas até à sua desactivação, durante a primeira metade do século XIII, momento em que todos os silos foram devidamente atulhados e selados, na sequência da conquista definitiva do Castelo de Palmela pelos exércitos cristãos, no final do século XII e, da ocorrência de profundas transformações da fortificação medieval, após a sua conquista (Fernandes, 2004), ficando assim localizados extramuros da muralha medieval cristã. Os silos escavados na rocha base e apresentam formato ovalado, com diferentes dimensões, variando entre os $0,90 \mathrm{~m}$ de diâmetro e os $3,45 \mathrm{~m}$, e com profundidades oscilando entre os $0,40 \mathrm{~m}$ e os $3,20 \mathrm{~m}$. A maioria destas estruturas negativas tinha pouca capacidade de armazenamento, com excepção do silo de grandes dimensões (Silo 6 - U.E. [217/218]). Nenhum dos silos tinha o bocal estruturado, pelo menos preservado, e alguns encontravam-se sela- 
dos com blocos pétreos de tamanho médio e grande, por vezes argamassados.

A área onde se localizam os silos islâmicos, que corresponde às sondagens 1 e 3 (Fotos 1 e 2), estava delimitada a sul por um muro em alvenaria (Muro 1 -U.E. [22] - sondagem 1 e U.E. [230] - sondagem 3), que se estendia no sentido nascente-poente e que poderia corresponder, a uma estrutura de apoio, de âmbito residencial ou defensivo do tipo barbacã.

Sobre esta última hipótese temos algumas reservas, na sua classificação, como parte de um sistema defensivo tendo em consideração as características que apresentava, um vez que não se tratava de uma sólida construção, tendo apenas $0,57 \mathrm{~m}$ de largura máxima registada na sondagem 1 . No entanto, a sua implantação no limite desta plataforma com acentuada vertente a sul, confere-lhe boas condições defesa não justificando uma construção robusta, razão pela qual não podemos excluir esta interpretação. A vala de fundação do Muro 1 (U.E. [22b] e [31]) na sondagem 1 foi escavada integralmente (lados norte e sul), e permitiu perceber que foi aberta no substrato geológico, prolongando-se para a sondagem 3. Nesta sondagem a vala de fundação (U.E. [229]) do Muro I (U.E. [230]) cortava e aproveitava estruturas pré-existentes, nomeadamente os silos 9, 11 e 12 (U.E.'s [224], [233] e [234], respectivamente). Admitimos que a cronologia da construção do muro 1 possa balizar-se entre os séculos XI e os inícios do XII, sendo eventualmente, posterior à construção de grande parte dos silos. Não foi possível clarificar a planta da estrutura que delimitava os silos medievais devido ao mau estado de preservação em que se encontrava, e também por não se ter identificado a sua continuidade, nas vertentes poente e nascente, da área intervencionada. A presença de uma vala (U.E. [231]) no limite poente da sondagem 3 corta, aparentemente, o Muro 1 no sentido sudoeste - nordeste, o que poderá indicar um hipotético cunhal desta estrutura que já não se preservava, ou até corresponder ao vestígio da destruição deste muro em séculos posteriores, talvez resultado da construção do recinto abaluartado na época moderna ou da transformação do sistema defensivo medieval. Para nascente, na sondagem 1 , o afloramento surge praticamente à superfície, não se conseguindo observar a continuidade do muro, ainda que o seu negativo desenhado na rocha base, ligeiramente afeiçoada nos sugira a sua presença. O piso de argamassa de cronologia moderna encontrava-se à mesma cota do afloramento rochoso, este que se apresentava regularizado para aproveitamento como piso de circulação, facto que terá apagado os vestígios do muro medieval.

Na sondagem 1 identificaram-se restos osteológicos humanos (U.E. [25]) que se encontravam depositados sobre o afloramento geológico e junto à vala de fundação do muro 1, no lado norte. Este conjunto era constituído por três fragmentos de ossos, nomeadamente pela tíbia direita, o fémur direito e a fíbula direita pertencentes a dois indivíduos adultos do sexo feminino. Trata-se de um depósito secundário segundo a análise antropológica realizada in situ, e a sua origem levanta muitas dúvidas, enquadrando-se num dos momentos mais conturbados da história do castelo, na segunda do século XII.

Observou-se, na sondagem 3 que a base da muralha sul assentava sobre uma estrutura pré-existente (U.E. [206]), cuja funcionalidade não podemos determinar, e que se caracterizava por um aparelho irregular, constituído por blocos pétreos de calcoarenito local, de calibre médio e grande, unidas por argamassa. Possuía visível, $3 \mathrm{~m}$ de comprimento, por aproximadamente $0,40 \mathrm{~m}$ de altura, por $0,20 \mathrm{~m}$ de largura, e assenta directamente no substrato geológico.

A existência em todas as sondagens de um piso de argamassa está associada ao nível de circulação do recinto abaluartado, ou até a um melhoramento do solo no decorrer do século XVIII. Esta estrutura demarcava bem a diferenciação cronológica dos artefactos identificados e recolhidos, contribuindo para a preservação das estruturas medievais precedentes. Os vestígios de ocupação humana mais antiga são pouco expressivos no registo e são testemunhados por artefactos cerâmicos e líticos, enquadrados no 2./. 1.ำ milénios a.n.e. Era já referida a presença de cerâmicas campaniforme com decoração linear-pontilhada associada à incisa do Grupo Palmela, datada do último quartel do 3. ․ milénio a.n.e. e também, alguns exemplares da Idade do Bronze (Fernandes e Carvalho, 1993:10; Fernandes, 2004: 235 e Fernandes e Santos, 2008:73). Presentemente, a intervenção realizada na encosta sul revelou que o cerro do castelo foi efectivamente, ocupado no final do $3 .^{\circ} \mathrm{e}$ durante 0 2.. / $1 .$. milénios a.n.e., como nos comprovam os vestígios materiais aqui recolhidos e outros dados, provenientes das restantes áreas escavadas no castelo. No caso, individualizamos nas unidades estratigráficas mais antigas e, que revestem o afloramento rochoso desta plataforma ou no enchimento dos silos, alguma indústria lítica maioritariamente 
em sílex e quartzito, alguns recipientes de cerâmica manual, por vezes decorada, e na sua maioria, brunidas. Destacamos, a presença de cerâmica decorada por traços brunidos, ainda que não tenhamos conseguido individualizar os contextos preservados, desta ocupação do Bronze Final / I. . Idade do Ferro, nem de períodos cronológicos anteriores, consequência das sucessivas reocupações e utilizações da fortificação promovidas por muçulmanos e cristãos. No conjunto da informação exumada, outros materiais remetem-nos para os contextos de uma ocupação romana, sobretudo tardia, prévia à construção da fortificação Omíada e igualmente, individualizada nas intervenções realizadas na alcáçova e junto à muralha norte-nascente. Documentamos na área de intervenção formas abertas de Terra Sigillata Clara e um numisma (materiais em estudo). A presença de contextos e materiais das ocupações pré-islâmicas foi igualmente, registada nas intervenções coordenadas por I. C. Fernandes, através do reaproveitamento de elementos arquitectónicos em mármore branco, nas muralhas e habitações Omíadas nomeadamente, os dois capitéis decorados com volutas, os dois fustes de coluna integrados num sistema de escoamento da muralha islâmica e um fragmento de friso (?), reutilizado como tabuleiro de jogo do 'Alquerque dos 9'. Estas evidências, a par dos vestígios materiais recolhidos na Encosta sul do Castelo, reforçam a possibilidade de existir uma anterior edificação da Antiguidade Tardia, ocupada até finais do século VIII e inícios do IX, posteriormente destruída/desmantelada pelos muçulmanos (Fernandes, 2004: 221).

Os artefactos de cronologias mais recuadas foram recolhidos em diferentes estratos sedimentares, que antecedem a formação rochosa de base - plataforma sul - ou no enchimento de alguns silos desprovidos dos seus contextos originais.

\subsubsection{O silo 6 - U.E. [217/218]}

A atribuição de unidades distintas, a este silo, deve-se à observação inicial, de duas manchas com coloração mais escura no substrato geológico, facto que parecia indicar a presença de duas estruturas negativas diferentes. Porém, durante a escavação em simultâneo destas U.E.'s determinou-se que se tratava de um silo de grande dimensão e cuja realidade estratigráfica era igual (Foto 3). A superfície do substrato geológico, em especial na área onde se registou a U.E. [217] mostrava sinais de abatimento da cobertura do silo, realidade testemunhada no seu enchimento, observando-se no perfil, o deslizamento dos sedimentos, resultante de um fenómeno natural, eventualmente fruto de algum terramoto, ocorrido após a desactivação do silo e posterior, à primeira metade do século XIII.

Escavado no substrato geológico (U.E. [214]), apresentava uma secção oval, com cerca de 3,20 m de profundidade, por 3,45 $\mathrm{m}$ de largura e tinha um bocal com cerca de $2 \mathrm{~m}$ de diâmetro. Estava selado com fragmentos de telha de canudo, alguns com decoração pintada e blocos pétreos, de médio e grande calibre. Compreendia quatro depósitos camadas no seu enchimento (U.E.'s [218A], [218B], [218C] e [218D]), associados a carvões e cinza, juntamente com restos faunísticos, objectos metálicos (fragmentos de peças de armamento, moedas e outros objectos indeterminados), ecofactos (algumas sementes carbonizadas e coprólitos), fragmentos de mós, e inúmeros fragmentos de cerâmica (doméstica, armazenamento e de construção). A estratigrafia do seu enchimento forneceu a seguinte leitura (Figura 3 ):

U.E. [218A]: Sedimento arenoso, pouco compacto, granulometria média, e cor castanha. Contém inúmeros fragmentos de telha, blocos pétreos de médio e grande calibre, fragmentos de cerâmica, metais, carvões e fauna.

UE [218B]: Sedimento arenoso, pouco compacto, granulometria média e cor cinzenta. Presença de recipientes cerâmicos, elementos metálicos, carvões, ecofactos e fauna.

UE [218C]: Sedimento pouco compacto com textura arenosa granulometria mediana e cor castanho-acinzentada. Contém espólio cerâmico (doméstico e de armazenamento), carvões, metais, ecofactos e fauna.

UE [218D]: Sedimento arenoso, com pouca resistência e de grão médio, apresenta cor castanho-acinzentada. Recolheram-se fragmentos cerâmicos, elementos metálicos-carvões e fauna.

\subsection{Espólio}

O espólio resultante desta intervenção contabiliza mais de 20000 exemplares, incorporando recipientes cerâmicos de funcionalidade e tipologia distintas, artefactos e elementos metálicos, ecofactos, vestígios osteológicos de origem humana, restos faunísticos, fragmentos de vidro e materiais líticos (pedra lascada e polida). A cronologia das diferentes materialidades recolhidas vai desde a pré-história até ao período contemporâneo. 
O que aqui apresentamos sumariamente pertence ao silo 6 (U.E. [217/218]) e corresponde a uma primeira selecção dos materiais, privilegiando os artefactos cerâmicos de cronologia atribuível, entre a segunda metade do século XII e a primeira metade do século XIII. O estudo ainda preliminar dos artefactos permitiu concluir que o grupo das cerâmicas é predominante no registo e que as recolhidas neste contexto ocupacional são maioritariamente de uso doméstico, destacando-se as formas de cozinha (panelas e testos), de armazenamento e transporte (cântaros, talhas, potes), os recipientes de servir à mesa (tigelas, pratos, jarras, púcaros, copos), os recipientes de iluminação (queimador; candil), de uso doméstico (mealheiro) e lúdico (malhas de jogo). São também numerosos os artefactos e elementos metálicos, em especial numismas e associados ao armamento (pontas de virote, pontas de seta, fragmentos de lâminas ou de lanças e esporas) e líticos (projecteis de catapultas), e ecofactos, em especial coprólitos.

As cerâmicas apresentam pastas bem depuradas e calibradas na generalidade, com presença de grãos de sílica; abundante mica, quartzo e quartzitos, algumas partículas de cerâmica moída e calcário. A dimensão dos elementos não plásticos (E.N.P.) é na maioria pequena, por vezes, e sobretudo nas pastas claras, muito fina (inferior a $2 \mathrm{~mm}$ ) denunciando uma depuração cuidada das pastas. Registam-se sobretudo em exemplares de armazenamento e transporte ou de cozinha, mas em número pouco expressivo, a presença de grãos de média dimensão (entre 3 a $5 \mathrm{~mm}$ ). Nas tipologias cerâmicas (Figura 4) há um predomínio da Panela - globulares, ovóides e bitroncocónicas -, seguindo-se as tampas, jarras/jarros e cântaros; os púcaros e copos; as tigelas, caçoilas, pratos e alguidares. Verifica-se que muitos recipientes tinham função mista, não sendo fácil fazer corresponder tipo e funcionalidade (Ex. panela/pote; tigela/caçoila). Uma determinada peça poderia ser usada como recipiente de cozinha, mas também como louça de mesa ou mesmo, para armazenar bens/produtos alimentares. As cerâmicas foram produzidas em ambientes irregulares, revelando as superfícies externas e internas oscilação de tonalidades relativamente ao núcleo da pasta, entre os cinzentos e castanhos, os vermelhos e laranjas, os beges, brancos e rosados. Os tratamentos das superfícies são diversificados estando presentes embora em menor percentagem, as peças que não sofreram qualquer acabamento, as revestidas por engobe incluindo também o grupo das vidradas, e as alisadas e brunidas. Os exemplares de cerâmica comum e pintada a branco são os predominantes, tratando-se de recipientes de uso quotidiano para confecção, consumo e armazenamento de produtos e alimentos. Porém são igualmente expressivos os exemplares de pastas claras, com pintura a vermelho, castanho e negro, correspondendo a formas de ir à mesa, de armazenamento e consumo e de iluminação (ex. jarras, cântaros, copos, púcaros, bules, candis). Também presentes no interior dos silos e associadas às unidades estratigráficas dos séculos X-XI, mas em menor abundância, surgem as peças vidradas - os vidrados a verde, amarelo melado, e as verde e manganês. Também a técnica da incisão, se encontra bem documentada e mais esporádicas temos as impressões digitadas, os cordões plásticos, as estampilhas.

As tipologias que estudamos aproximam-se das formas conhecidas na cidade de Lisboa (Bugalhão \& Folgado, 2001), Loulé (Catarino, 1997/98), Mértola (Gómez-Martinez, 2004), Palmela (Fernandes, 2004), Santarém (Viegas \& Arruda 1999), Sintra (Sousa, 2015) e Silves (Gomes \& Gomes, 1991).

Ainda na categoria das cerâmicas, destacamos as de produção manual, que nos parecem enquadráveis e representativas dos contextos das comunidades precedentes que ocuparam o cerro do castelo de Palmela, durante o 2.. /1.$^{\circ}$ milénios a.n.e. No reportório individualizaram-se as formas abertas e fechadas, de uso doméstico e armazenamento de bens alimentares. Tipologicamente, registaram-se alguns fundos planos provavelmente de potes e vasos, um bordo com lábio boleado (U.E. [22C] - Sondagem 1) e um fragmento de parede com carena de uma taça (Sondagem 3, silo 6). Na sua maioria os fragmentos apresentam pastas bem depuradas e calibradas, com abundantes elementos não plásticos compostos por mica, quartzo, quartzitos e distintos minerais que não conseguimos caracterizar, com uma simples observação a olho. De um modo geral, os grãos são muito finos a finos ( $\leq 2 \mathrm{~mm})$, observam-se por vezes, elementos de grande calibre ( $\geq 5 \mathrm{~mm})$, associados a pastas mais rudimentares e grosseiras. Nas tonalidades das pastas e das superfícies prevalecem, as cores negro e castanho, denunciando ambientes de cozedura redutores ou em alguns casos, ambientes mais instáveis, com cozeduras irregulares.

A maioria das peças apresenta revestimento com engobe espesso e aderente, embora as superfícies muito erodidas, preservem ainda visível, o brunido e po- 
limento aplicado no exterior e interior do fragmento. No interior do silo 6, na U.E. [218C] recolheram-se fragmentos de cerâmica manual, com decoração brunida em traços nomeadamente, o fragmento decorado com os "ornatos brunidos» (vaso?) estilo "Lapa do Fumo». A decoração incide apenas na superfície externa.

$\mathrm{Na}$ indústria lítica estão presentes os materiais em pedra lascada e em pedra polida (percurtor?), surgindo alguns núcleos prismáticos esgotados em sílex, lamelas, lâminas e lascas em sílex, quartzo e matéria siliciosa e abundantes restos de talhe.

No conjunto dos metais, os numismas contabilizam um total de 251 exemplares, sendo que 182 foram retiradas do silo 6 - U.E. [217/218], um das quais é de cronologia romana (em estudo), e as restantes pertencentes aos reinados de D. Sancho I e D. Afonso II, séculos XII-XIII).

Os objectos em osso são representados por diversos botões (em osso, pasta vítrea e madrepérola), escova e pentes de cronologia moderna (séculos XVII/ XVIII), dois dados, um elemento de roca e uma peça de adorno decorada de cronologia atribuível ao século XII.

Os ecofactos estão testemunhados pela presença de algumas sementes, caroços e coprólitos recolhidos nos silos islâmicos, principalmente no silo 6 e no silo 10.

\section{CONSIDERAÇÕES PRELIMINARES}

Os trabalhos permitiram determinar que a ocupação na fase islâmica se estendia por toda a plataforma superior do castelo até ao lado sul, testemunhado pela existência de 11 silos de diferentes tamanhos e de um de grandes dimensões, delimitados a sul, por um muro em alvenaria. Esta área teve como principal função o armazenamento de alimentos, eventualmente destinada à guarnição do castelo, ou ao abastecimento da população que habitava às portas do castelo durante os séculos X/XI e XII. O uso pleno destas estruturas deverá ter sido prolongado, até aos meados ou finais do século XII, quando ocorrem as primeiras conquistas cristãs. $\mathrm{O}$ abandono e encerramento definitivo destas estruturas ocorre justamente, após a última conquista do castelo, em 1196, permanecendo subterradas/seladas e extramuros do castelo, aquando a reformulação da sua estrutura defensiva ao longo do século XIII.

A proposta da evolução da fortificação desde a sua fundação, no século VIII/IX, defendida por I. C. Fernandes (2004), aponta para no início da ocupação islâmica o castelo, desenhar um recinto de planta rectangular de menores dimensões, que se vai expandindo e transformando nas fases seguintes, admitindo-se que na restante área da plataforma superior - alcáçova -, e ao longo da encosta sul, se pudessem concentrar estruturas habitacionais e outras dedicadas ao aprovisionamento da população, como nos parecem sugerir as realidades agora escavadas. A insegurança vivida neste território originada pelas investidas e pelo avanço dos exércitos cristãos nos territórios a Sul do rio Tejo, bem como pelos ataques viquingues que assolaram a costa portuguesa anteriormente, no século $\mathrm{X}$, podem justificar a necessária proximidade da população à fortificação, como refúgio de defesa. São também conhecidos historicamente algumas destruições no castelo, em especial com a violenta incursão almóada, obrigando a algumas reparações e alterações já sob gestão cristã. Terá sido numa destas alturas de maior instabilidade na fronteira entre o cristianismo e o islamismo, que o muro (U.E. [22] / [230]) terá sido erguido, aproveitando os silos (U.E.'s [333] e [334]) como fundação. A identificação da fundação da muralha sul sobre uma estrutura pré-existente (U.E. [306]) parece um claro indicador da evolução da fortificação, a partir do século XIII, com reforço da cerca e de construção de novas torres, nomeadamente da Torre 8 (Fernandes, 2004: 244).

O contexto cronológico dos artefactos cerâmicos existentes no interior do silo 6 baliza-se entre o final do século XI e a primeira metade do século XII, do período Almorávida. A construção dos silos e a ocupação habitacional ou militar desta área poderá remontar ao século IX-X, com utilização destas estruturas, pelo menos ao até aos meados do século XII. O encerramento e a selagem dos silos terão acontecido num curto espaço de tempo, durante o avanço dos exércitos cristãos, no decorrer da segunda metade do século XII. Será entre os finais do século XII e o início do século XIII que toda esta área é abandonada, tendo por base os achados numismáticos recolhidos do silo 6 .

No final dos trabalhos arqueológicos todas as estruturas identificadas nas sondagens foram devidamente acondicionadas e aterradas, salvaguardadas novamente, por baixo de um piso argamassado, conforme solução prevista no projecto de execução.

Para terminar, sublinhamos a ocorrência de vestí- 
gios de várias cronologias que revelaram uma ampla diacronia de ocupação do cerro do castelo, com materialidades que vão desde a Pré-história recente até ao período Contemporâneo. Embora a leitura e interpretação segura sobre as primitivas ocupações, não sejam ainda possíveis podemos, agora, afirmar que previamente à construção do castelo, outras comunidades e culturas estiveram presentes neste lugar, destacado na paisagem e com uma implantação geográfica de absoluto domínio visual para a foz do Sado e um vasto território, a que afluíam diferentes pessoas, produtos, culturas, se não antes, pelo menos desde fins do $3 .{ }^{\circ}$ milénio a.n.e.

\section{BIBLIOGRAFIA}

BUGALHÃO, Jacinta e FOLGADO, Deolinda (2001) - O arrabalde ocidental da Lisboa islâmica: urbanismo e produção oleira in Arqueologia Medieval, n.. 7. Porto. Edições Afrontamento. pp. 111-145.

CATARINO, Helena (1997/98) - O Algarve Oriental durante a ocupação islâmica. Povoamento rural e recintos fortificados. Al-Ulyâ, Revista do Arquivo Histórico Municipal de Loulé, nำ6, Vols. I, II e III, Loulé.

FERNANDES, Isabel Cristina F. (2004) - O Castelo de Palmela do islâmico ao cristão. Palmela: Edições Colibri e Câmara Municipal de Palmela.

FERNANDES, Isabel Cristina F. e CARVALHO, A. Rafael (1993) - Arqueologia em Palmela, 1988-92. Catálogo da Exposição no Castelo de Palmela, 28 de Agosto a 19 de Dezembro de 1993. Palmela: Câmara Municipal de Palmela, pp. 10.

FERNANDES, Isabel Cristina F. e SANTOS, Michelle Teixeira (2008) - Palmela Arqueológica. Espaços. Vivências. Poderes. Catálogo da Exposição na Igreja de Santiago - Castelo de Palmela, 17 de Maio de 2008 a 18 de Maio de 2009. Palmela: Câmara Municipal de Palmela / Museu Municipal pp. 73.

GOMES, Mário Varela e GOMES, Rosa Varela (1991) - Cerâmicas Almoadas do Castelo de Silves in Actas do Congresso A Cerâmica Medieval no Mediterrâneo Ocidental, Campo Arqueológico de Mértola. Pp. 387-403.

GÓMEZ-MARTÍNEZ, Susana (2004) - Cerámica Islámica de Mértola: producción y comercio. [Recurso electrónico] Madrid: Servicio de Publicaciones dela Universidad Complutense de Madrid, ISBN: 84-669-2568-6.

PEREIRA, Luís Filipe (2019) - Intervenção Arqueológica no Castelo de Palmela - Resultados Preliminares in + Museu, Boletim do Museu Municipal de Palmela, n. . 20. Câmara Municipal de Palmela.

SOUSA, Maria João de (2015) - Uma habitação do Século XI/XII sob a muralha do Castelo dos Mouros de Sintra Evidências arqueológicas de um contexto doméstico, GON-
ÇALVES, M. J. e GÓMEZ-MARTINÉZ, S. Eds., Actas do X Congresso Internacional - A Cerâmica no Mediterrâneo, Vol. 1, Silves, C.M. Silves/Campo Arqueológico de Mértola, pp. 262-265.

VIEGAS, Catarina e ARRUDA, Ana Margarida (1999) - Cerâmicas islâmicas da alcáçova de Santarém. Revista Portuguesa de Arqueologia, Vol. 2, número 2, Lisboa, pp. 105-186. 


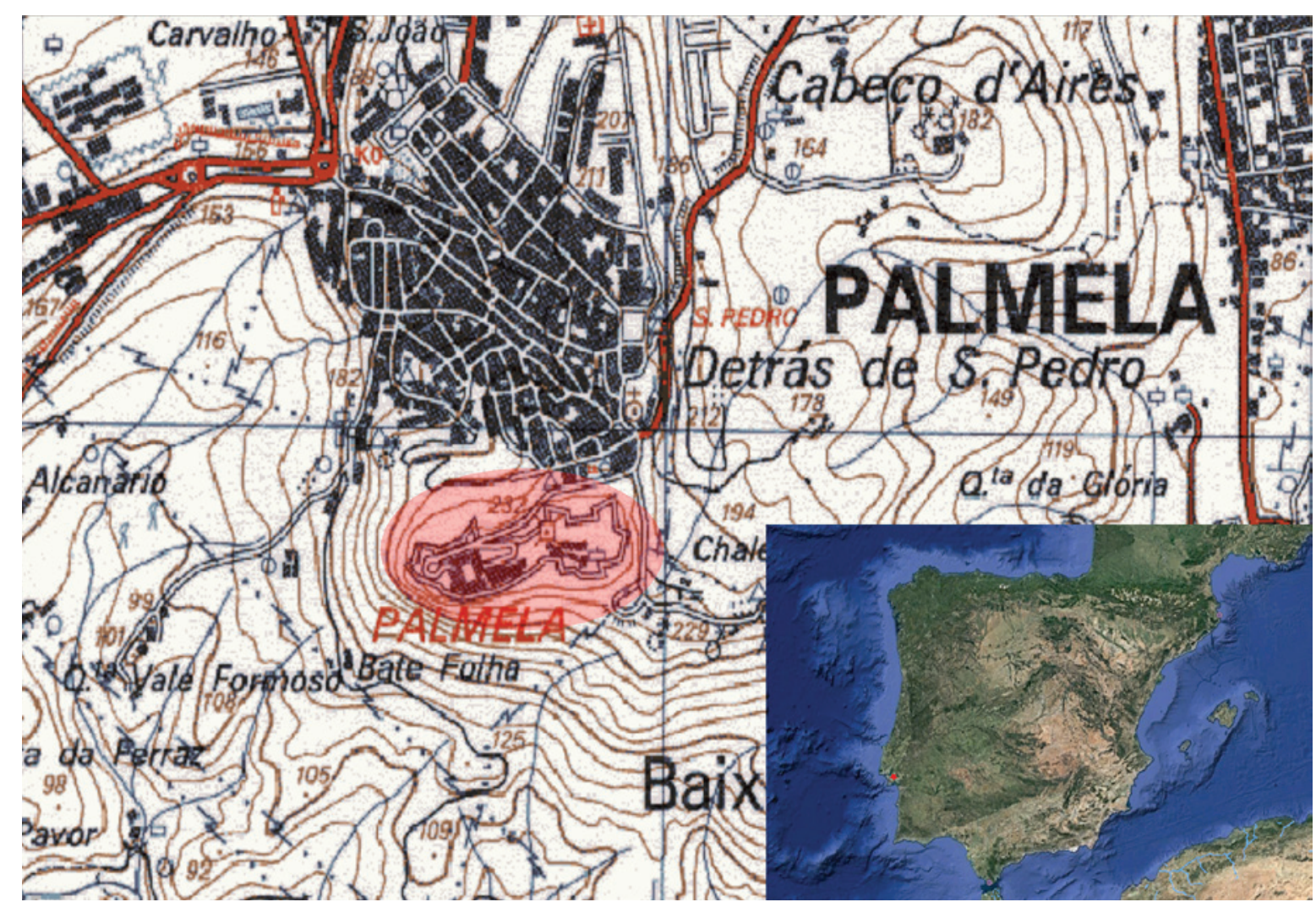

Figura 1 - Localização do Castelo de Palmela na Carta Militar de Portugal, n. ํ454, esc. 1:250oo.

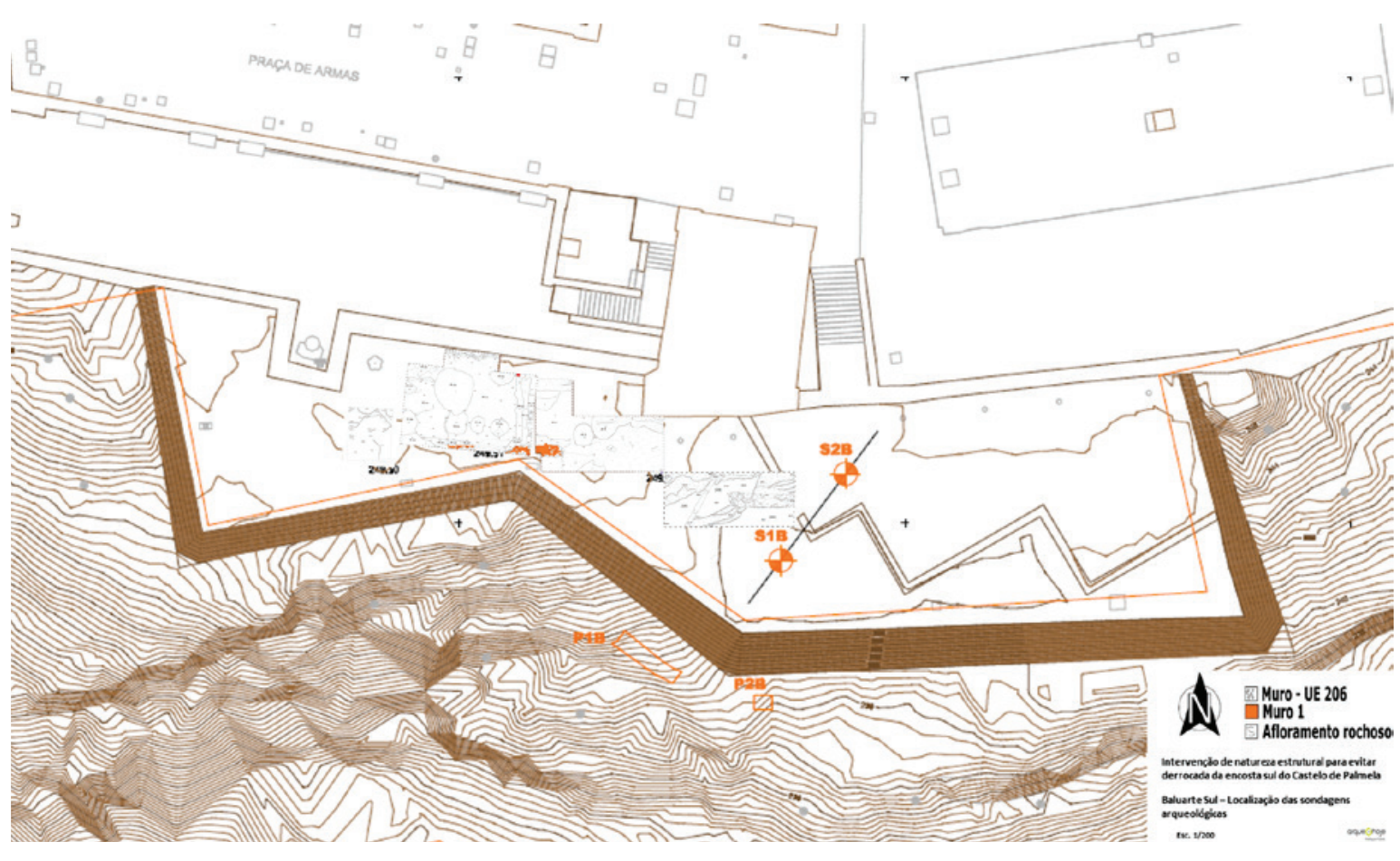

Figura 2- Localização das sondagens na planta do Castelo de Palmela - Baluarte Sul. Escala 1:20o. 


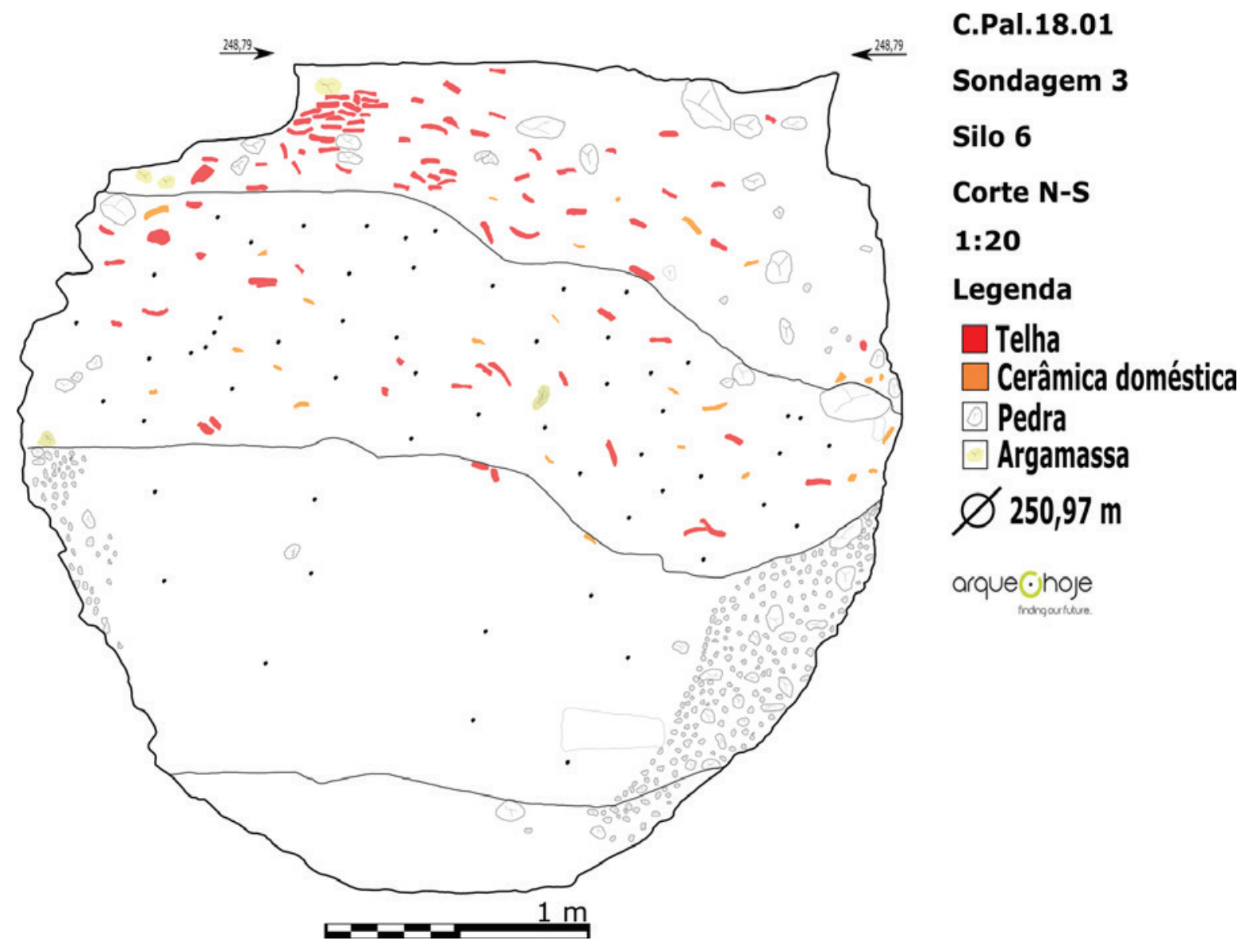

Figura 3 - Perfil do enchimento do Silo 6.

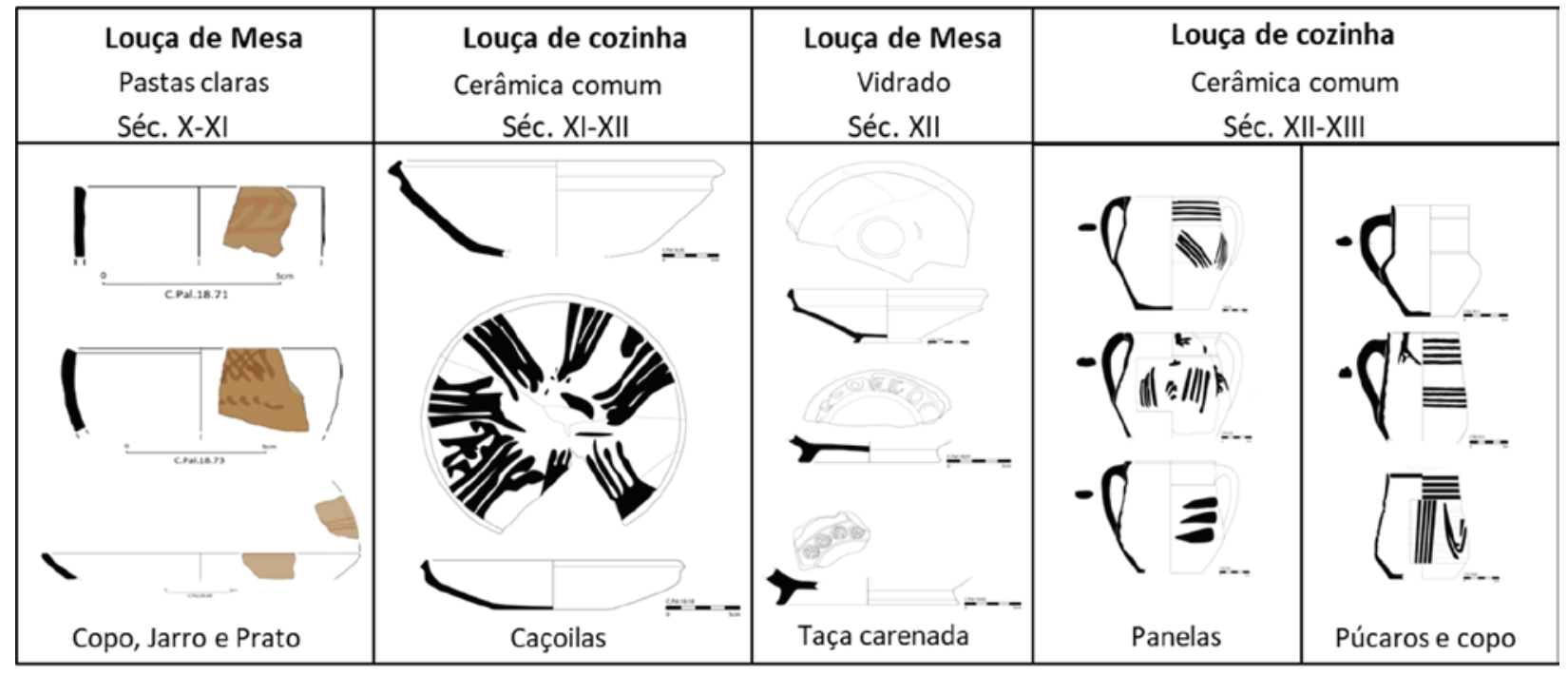

Figura 4-Tabela das diferentes tipologias de cerâmicas recolhidas no Silo 6. 


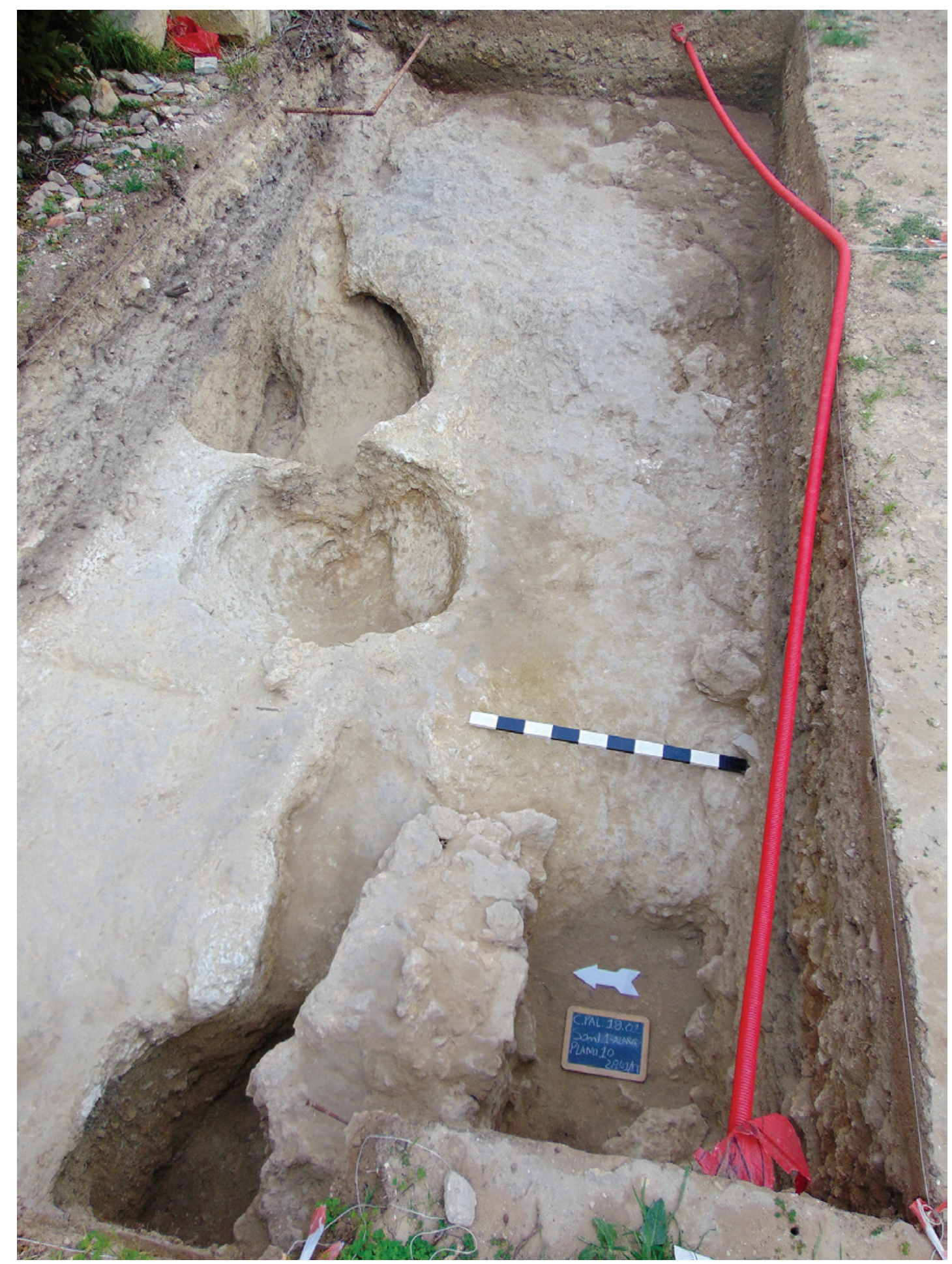

Foto 1 - Plano final da sondagem 1. Vista de Oeste. 


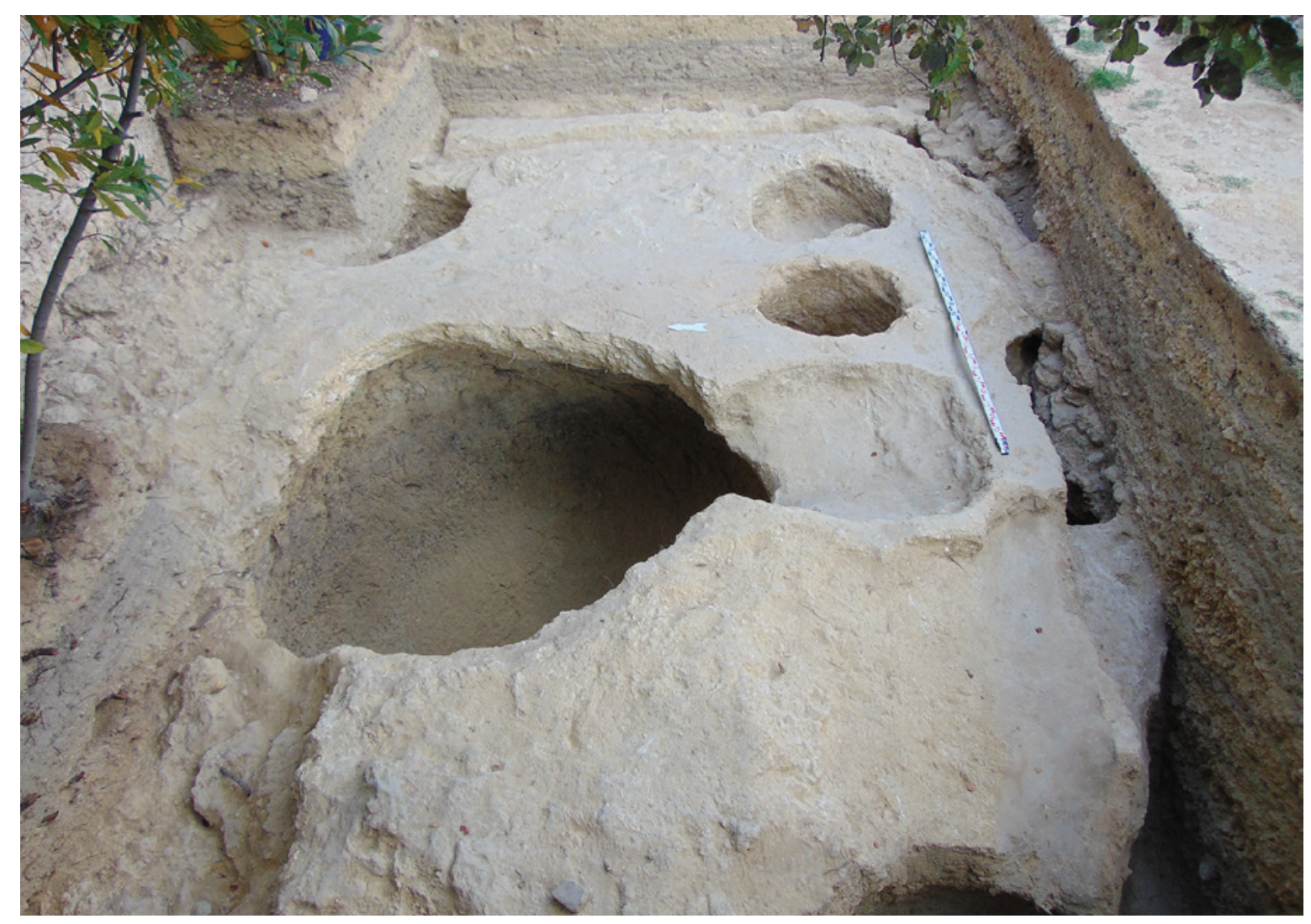

Foto 2- Plano final da Sondagem 3. Vista de Oeste.

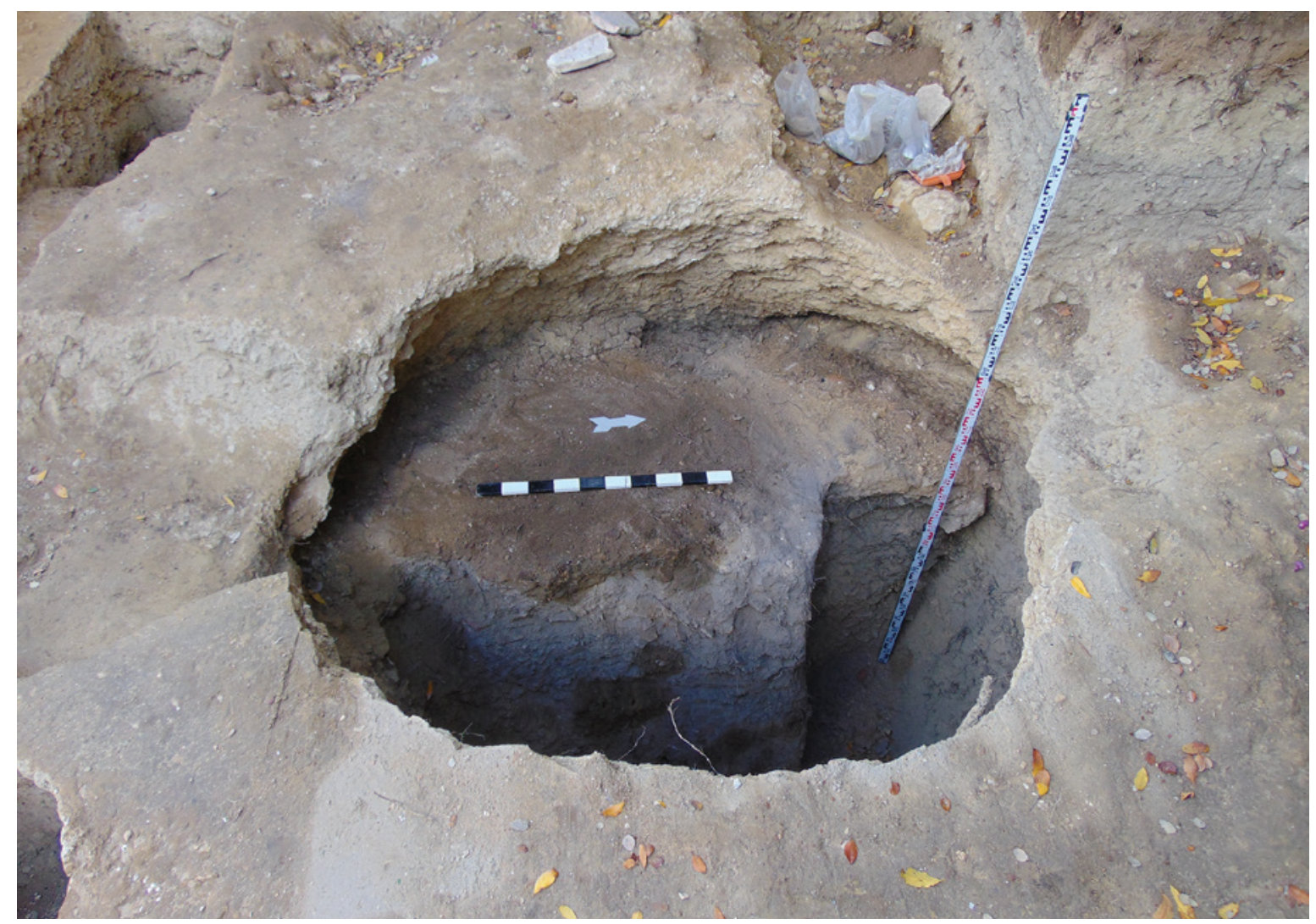

Foto 3 - Aspecto geral do Silo 6 durante a escavação do seu enchimento. 



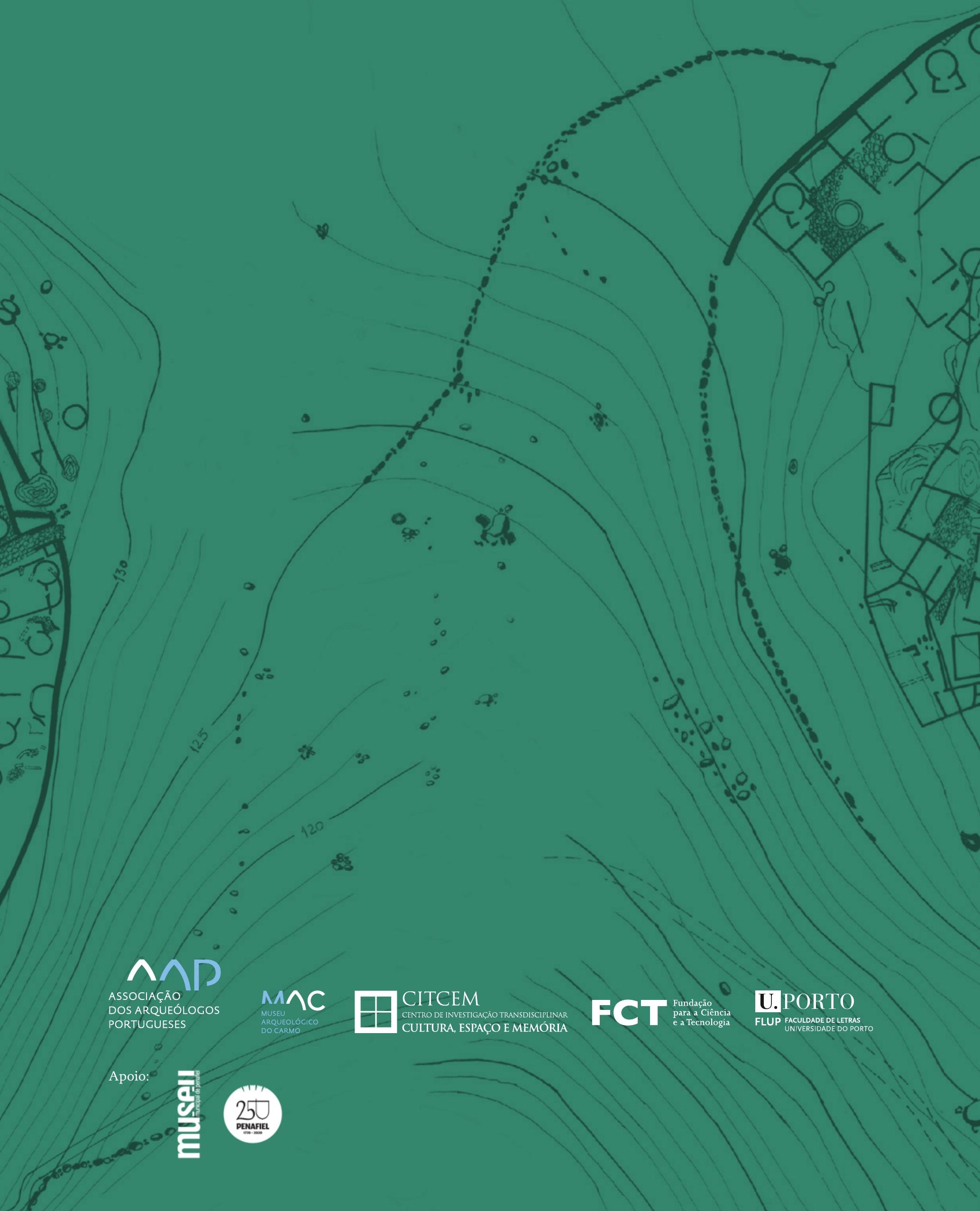

